\title{
METODE TERJAMAHAN TATA BAHASA DALAM PEMBELAJARAN MEMBACA KARANGAN EKSPOSISI
}

\author{
Nur Fitri Mardhotillah \\ Universitas Muhammadiyah Cirebon \\ Pos-el: Pietz_Mardhotillah@yahoo.com
}

\begin{abstract}
Abstrak
Penelitian ini didasari pembelajaran bahasa Sunda di SMPN 1 Susukan kabupaten Cirebon seperti pembelajaran bahasa asing karena bahasa sehari-hari yang digunakan adalah bahasa Cirebon. Siswa kurang mengenal kosakata dan memahami tata bahasa dari bahasa Sunda, dengan metode terjemahan tata bahasa diharapkan bisa membantu siswa dalam memperkaya kosakata dan memahami tata bahasa Sunda. Penelitian ini dilakukan untuk mengetahui seberapa besar pengaruh metode terjemahan tata bahasa terhadap kemampuan kosakata dalam membaca karangan eksposisi. Metode penelitian yang digunakan dalam penelitian ini adalah metode eksperimen dengan desain pretest and posttest control group desaign. Populasi penelitian ini yaitu siswa kelas IX dengan sampel siswa kelas eksperimen yaitu siswa kelas IX B dan sampel kelas kontrol siswa kelas IX G SMPN 1 Susukan Kabupaten Cirebon Taun Ajaran 2014/2015. Hasil penelitian menunjukkan bahwa metode terjemahan tata bahasa efektif dalam meningkatkan kemampuan kosakata dalam membaca karangan eksposisi siswa kelas IX SMPN 1 Susukan Kabupaten Cirebon taun ajaran 2014/2015.
\end{abstract}

Kata Kunci: Metode terjemahan tata bahasa, membaca karangan eksposisi.

\section{GRAMMAR TRANSLATION METHOD OF TEACHING READING OF EXPOSITION TEXTS}

\begin{abstract}
The Backgound of this study is the condition of Sundanese language teaching in SMPN 1 Susukan, Cirebon Regency, that is similar to foreign language teaching. It is because the daily language used is the Cirebon language. Students are less familiar with the vocabulary and the grammar of Sundanese. The grammar translation method is expected to help students in enriching vocabulary and grammar to understand the Sundanese. This study was conducted to determine the influence of the grammar translation method to the vocabulary skills in reading the exposition essays. The method used in this study is the experimental method with the design of pretest and posttest control group. The population is $9^{\text {th }}$ grade students with the sample consisting of the students of class IX B. The sample control consisted of students of class IX G. The results show that the grammar translation method is effective in improving student vocabulary skills in reading exposition texts.
\end{abstract}

Keywords: Grammar translation method, reading exposition text. 


\section{PENDAHULUAN}

Metode terjemahan tata bahasa ini sering digunakan dalam pembelajaran bahasa asing. Prinsip yang dijadikan landasan dalam metode ini adalah bahasa asing bisa tercapai dengan cara latihanlatihan terjemahan dari bahasa yang diajarkan terhadap bahasa sumber siswa atau sebaliknya. Latihan-latihan terjemahan merupakan latihan utama dalam metode terjemahan tata bahasa. Metode ini ditujukan untuk pembelajaran membaca dan menulis. Pentingnya metode ini diantaranya; (1) dengan menerjemahkan memberikan gambaran batasan-batasan materi pembelajaran dengan bahasa sumber, (2) siswa bisa memahami kosakata dan tata bahasanya, dan (3) memperkaya kosakata siswa. Oleh karena itu, tujuan pembelajaran yang ingin dicapai oleh metode ini dibatasi dengan kemampuan kosakata siswa dalam pembelajaran membaca karangan eksposisi.

Pentingnya kegiatan membaca salah satunya adalah dapat memperkaya kosakata. Tapi, karena bahasa yang digunakan dalam sehari-hari bahasa Cirebon/Jawa jadi pembelajaran membaca menjadi salah satu masalah dalam mengajarkan bahasa Sunda. Pembelajaran bahasa Sunda di SMPN 1 Susukan kabupaten Cirebon ini seperti pembejaran bahasa asing, siswa kurang mengenal kosakata bahasa Sunda jangankan untuk memahami maknanya, melafalkan vokal eu saja siswa sudah merasa kesulitan. Contonya dalam kata /jeung/ siswa melafalkannya [je-ung]. Sebenarnya minat belajar bahasa Sunda baik sekali tapi karena ada masalah mengenai bahasanya jadi masalah juga dalam menyampaikan materi yang sesuai dengan standar kompetensi dan kompetensi dasar (SKKD) mata pelajaran bahasa dan sastra Sunda dinas provinsi Jawa Barat. Contonya dalam pembelajaran membaca yang tergolong lebih mudah diajarkan dibandingkan dengan pembelajaran menulis.

Keterampilan membaca jadi kegiatan yang harus sering digunakan dalam pembelajaran bahasa Sunda di kabupaten
Cirebon hususna di kecamatan Susukan, dengan banyak membaca diharapkan dapat memperkaya kosakata yang dikuasai siswa. Hal ini sesuai dengan pendapat Nurhadi (2010: 3) bahwa pembaca yang baik itu yang kaya akan kosakata, kosakata merupakan modal utama membaca untuk modal membaca lainnya. Salah satu pembelajaran membaca di kelas IX adalah membaca karangan bahasan atau eksposisi. Masalah dalam pembelajaran membaca karangan eksposisi yang ditemukan dalam objek penelitian diantaranya; (1) siswa kurang mengenal kosakata dari bahasa Sunda, (2) siswa tidak memahami arti dari tiap kosakata dan tata bahasa Sunda, dan (3) penggunaan metode kurang variatif dan tidak sesuai dengan kompetensi dasar. Untuk mengatasi masalah-masalah di atas perlu metode yang sesuai dengan kompetensi dasarnya. Hal ini dilakukan supaya kemampuan siswa menguasai kosakata dalam membaca karangan eksposisi meningkat, dengan meningkatnya hasil diajar siswa diharapkan tujuan pembelajaran juga akan tercapai. Metode yang dianggap cocok untuk meningkatkan kemampuan kosakata siswa dalam membaca karangan eksposisi adalah metode terjemahan tata bahasa. Berdasarkan uraian di atas, peneliti bermaksud meneliti tentang metode terjemahan tata bahasa dalam pembelajaran membaca karangan eksposisi.

Metode terjemahan tata bahasa merupakan hasil karya pemikiran sarjana Jerman (Johann Seidenstucker, Karl Plotz, H.S. Ollendorf, jeung Johann Meidinger) yang tujuannya to know everything about samething rather than the thing it self atau untuk mengetahui segala sesuatu mengenai sesuatu dibanding ihwal itu sendiri. Di Amerika Serikat, sesungguhnya metode terjemahan tata bahasa ini pertama dikenal sebagai Metode Prussia. Metode terjemahan tata bahasa mendominasi pengajaran bahasa asing dari tahun 1840-an sampai tahun 1940-an, dan dalam bentuk yang telah dimodifikasipun tetap terpakai secara luas di beberapa bagian dunia ini sampai 
sekarang. Dalam bentuknya yang asli, metode terjemahan tata bahasa ini mempunyai ciri-ciri seperti berikut: (1) para siswa pertama-tama mempelajari kaidah tata bahasa dan daftar kosakata dwibahasa yang berkaitan erat dengan bahan bacaan pada pelajaran yang bersangkutan, (2) sekalipun kaidah dan kosakata dipelajari, petunjuk bagi penerjemahan latihan yang mengikuti penjelasan ketatabahasaan pun diberikan, (3) pemahaman akan kaidah dan bahan bacaan pun diuji melalui terjemahan (dari bahasa sasaran ke bahasa itu/bahasa asli, dan sebaliknya), (4) bahasa asli/bahasa ibu dan bahasa sasaran dibandingkan secara konstan, dan (5) memang sangat sedikit kesempatan bagi praktik/latihan menyimak dan berbicara selama metode ini memusatkan perhatian pada latihan membaca dan terjemahan. Kebanyakan waktu kelas tercurah pada pembicaraan mengenai bahasa, dalam kenyataan tidak ada waktu tersdia untuk berbicara dengan bahasa itu (Omaggio dalam Tarigan, 2009: 85). Secara singkat, kita dapat mengatakan bahwa metode terjemahan tata bahasa pada hakikatnya mencakup dua komponen, yaitu telaah eksplisit kaidah-kaidah tata bahasa dan kosakata, dan penggunaan tejemahan. Harus kita sadari bahwa"terjemahan" merupakan komponen tertua dan barangkali paling tua dari semua metode pengajaran yang pernah dipakai pada masa Yunani dan Romawi kuno serta di tempat-tempat lain di dunia kuno. Aspek tata bahasa memang agak minim dan terbatas pada masa itu, sedangkan pengetahuan ketatabahasaanpun terbatas pula. Dengan pertumbuhan pengetahuan ketatabahasaan, komponen ketatabahasaan memainkan peranan yang lebih besar dalam pengajaran, yang pada akhirnya mendominasi aspek terjemahan. Pada akhir abad ke-18 di Eropa, hal ini justru menjadi pasangan utama dalam metode tersebut, bahkan secara nyata tercakup dalam nama metode itu: metode terjemahan tata bahasa (MTTB). Pertumbuhan dan perkembangan komponen ketatabahasaan berlangsung secara berkesinam- bungan terus sampai sekarang. Kaidahkaidah dijelaskan oleh guru, kemudian dihafal, diceritakan kembali dan diterapkan oleh siswa.

Dalam MTTB ini, bahasa disajikan dalam pelajaran ketatabahasaan singkat yang masing-masing memuat beberapa kaidah tata bahasa, yang disusun serta diilustrasikan dengan contoh-contoh. Ciriciri ketatabahasaan memang menjadi fokus perhatian dalam buku pelajaran dan pada pelajaran yang diberikan oleh guru tidaklah disembunyikan atau ditutup-tutupi. Istilahistilah teknis ketatabahasaan tidak dihindari. Pembelajar diharapkan dapat menelaah, mengkaji, dan menghafalkan kaidah tertentu beserta contohnya, misalnya paradigma verba atau daftar preposisi.

Berdasarkan uraian di atas, MTTB ini mempunyai keunggulan dan kelemahan. Letak keunggulan yang dimaksud diantaranya; (1) kelas-kelas besar dapat diajar, (2) guru yang tidak fasih pun dapat dipakai, dan (3) cocok bagi semua tingkat linguistik para siswa (pemula, lanjutan, mahir), para siswa dapat memperoleh aspek-aspek bahasa yang signifikan dengan bantuan buku tanpa pertolongan guru. Sedangkan letak kelemahan MTTB ini yaitu; (1) secara linguistik dibutuhkan guru yang terlatih, (2) kebanyakan pokok bahasan (subject matter) tidak mengenai orang tertentu, dan terpisah serta terpencil dari yang lain, dan (3) tidak sesuai bagi orang yang tuna aksara, misalnya anak kecil atau imigran tertentu, sedikit sekali bahasa yang digunakan bagi komunikasi antara pribadi, kesempatan bagi pengemukaan tuturan atau ujaran spontan sangan terbatas (Steinberg dalam tarigan, 2009: 90-91).

\section{Membaca Karangan Eksposisi}

Membaca adalah suatu kegiatan atau cara dalam mengupayakan pembinaan daya nalar (Tampubolon, 1987:6). Dengan membaca, seseorang secara tidak langsung sudah mengumpulkan kata demi kata dalam mengaitkan maksud dan arah bacaannya yang pada akhirnya pembaca dapat 
menyimpulkan suatu hal dengan nalar yang dimilikinya. Pengertian lain dari membaca adalah suatu keterampilan yang kompleks, yang rumit, yang mencakup atau melibatkan serangkaian keterampilan-keterampilan yang lebih kecil. Dengan kata lain, keterampilan membaca mencakup tiga komponen: (1) pengenalan terhadap aksara serta tanda-tanda baca, (2) korelasi aksara beserta tanda-tanda baca dengan unsurunsur linguistik yang formal, dan (3) hubungan lebih lanjut dari (1) dan (2) dengan makna atau meaning (Broughton dalam Tarigan, 2009:11).

Tujuan utama membaca adalah untuk mencari serta mendapatkan informasi, meliputi isi dan memahami makna bacaan. Tarigan (2008:9-10) mengelompokkan membaca menjadi beberapa jenis, diantaranya:

a) Membaca untuk mendapatkan rincianrincian atau fakta-fakta (reading for details or fact)

b) Membaca untuk mendapatkan ide-ide utama (reading for main idea)

c) Membaca untuk mengetahui urutan atau susunan, organisasi cerita (reading for sequence or organization)

d) Membaca untuk menyimpulkan, membaca inferensi (reading for inference)

e) Membaca untuk mengelompokkan (reading for classify)

f) Membaca untuk menilai, membaca mengevaluasi (reading for evaluate)

g) Membaca untuk membandingkan (reading to compare or contrast)
Syafii (1994:6-7) menyebutkan hakikat membaca adalah: (1) pengembangan keterampilan memahami kata-kata, kalimat-kalimat, paragraf-paragraf dalam bacaan sampai dengan memahami secara kritis dan evaluatif keseluruhan isi bacaan; (2) kegiatan visual, berupa serangkaian gerakan mata dalam mengikuti baris-baris tulisan, pemusatan penglihatan pada kata dan kelompok kata, melihat ulang kata dan kelompok kata untuk memperoleh pemahaman terhadap bacaan; (3) kegiatan mengamati dan memahami kata-kata yang tertulis dan memberikan makna terhadap kata-kata tersebut berdasarkan pengetahuan dan pengalaman yang telah dipunyai; (4) suatu proses berpikir yang terjadi melalui proses mempersepsi dan memahami informasi serta memberikan makna terhadap bacaan; (5) proses mengolah informasi oleh pembaca dengan menggunakan informasi dalam bacaan dan pengetahuan serta pengalaman yang telah dipunyai sebelumnya yang relevan dengan informasi tersebut; (6) proses menghubungkan tulisan dengan bunyinya sesuai dengan sistem tulisan yang digunakan; dan (7) kemampuan mengantisipasi makna terhadap baris-baris dalam tulisan. Kegiatan membaca bukan hanya kegiatan mekanis saja, melainkan merupakan kegiatan menangkap maksud dari kelompok-kelompok kata yang membawa makna. Broughton mengungkapkan dua aspek penting dalam membaca yang dibagankan seperti di bawah.

Kedua aspek tersebut bisa dilihat dari bagan di bawah ini. 


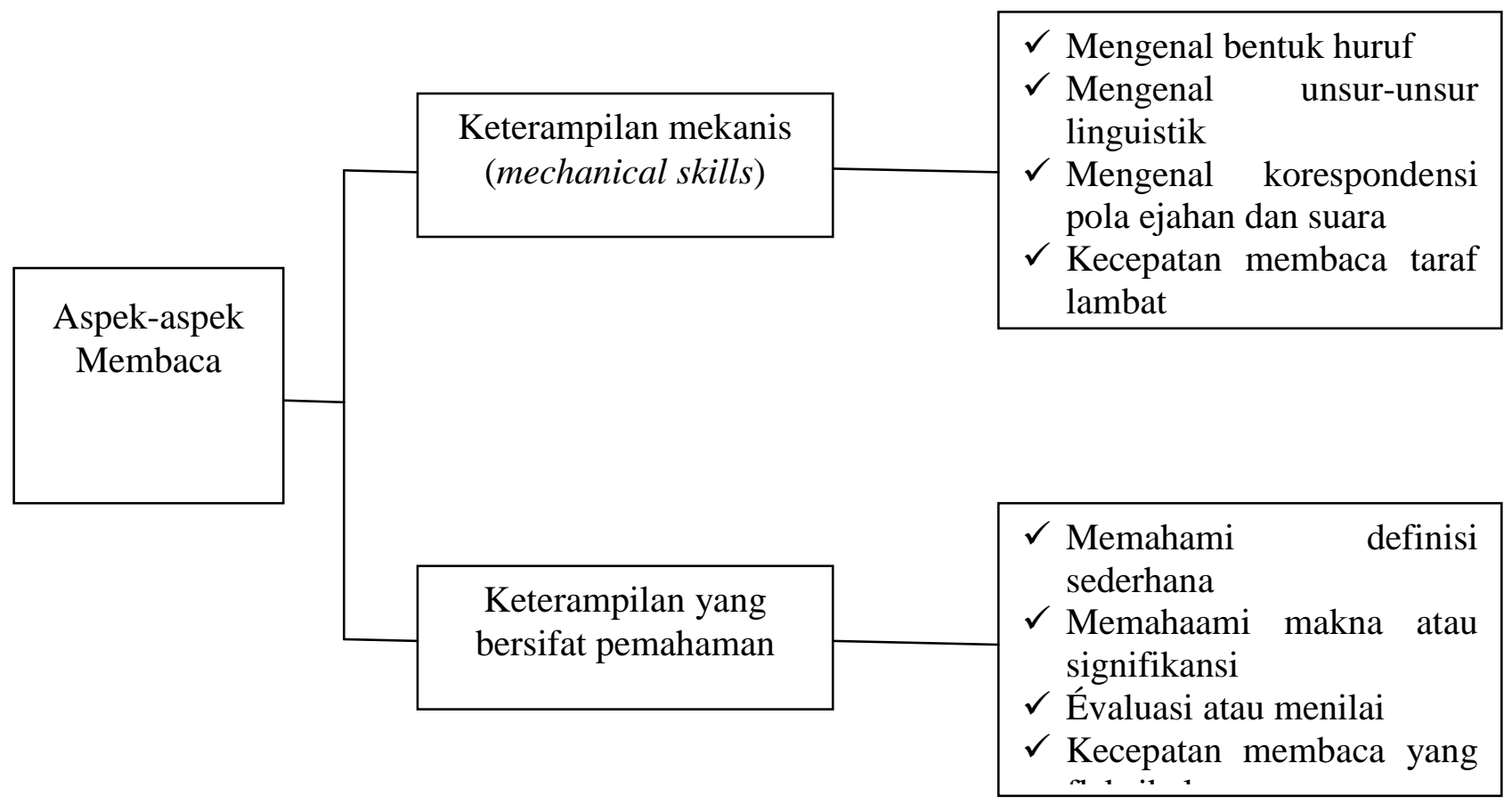

(Broughton dalam Tarigan, 2008:14)

Bagan 2.1 Aspek Maca

Untuk mencapai tujuan yang ada dalam keterampilan mekanis diperlukan membaca nyaring (reading alound, oral reading), sedangkan untuk mencapai tujuan yang ada dalam keterampilan yang sifatnya pemahaman adalah dengan membaca senyap (silent reading) yang terbagi dalam membaca ekstensif (extensive reading) dan membaca intensif (intensive reading). Yang tergolong membaca ekstensif meliputi; a) membaca survey (survey reading), b) membaca sakilas (skimming), jeung c) membaca dangkal (superficial reading). Sedangkan yang tergolong membaca intensif diantaranya; a) membaca telaah eusi (content study reading) yang meliputi membaca teliti (close reading), membaca pemahaman (comprehensive reading), membaca kritis (critical reading), dan membaca ide (reading for ideas), b) membaca telaah bahasa (language study reading) yang meliputi membaca bahasa asing (foreign language reading) dan membaca sastra (literary reading).

Untuk mendapatkan gambaran mengenai gambaran mengenai jenis membaca yang telah diuraikan di atas, bisa dilihat dari skema berikut. 


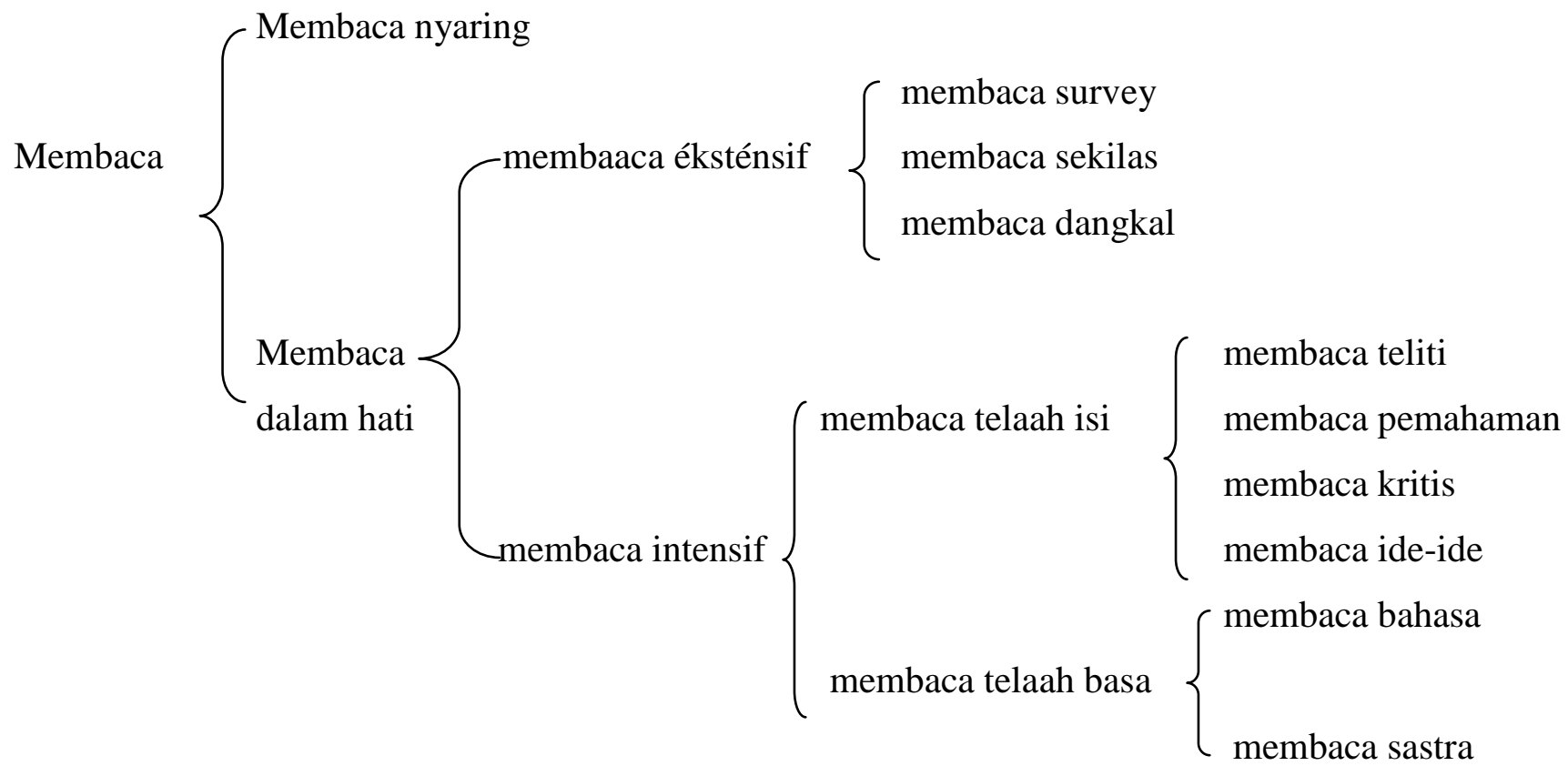

Aspek yang dinilai dari kegiatan membaca karangan eksposisi ini baik di kelas eksperimen maupun kelas kontrol bukan menilai kemampuan membaca pemahaman melainkan kemampuan kosakata dari hasil membaca karangan eksposisi. Dari jenis bacaan karangan eksposisi atau karangan yang bertujuan untuk memberi tahu, mengupas, menguraikan, atau menerangkan sesuatu ini siswa diminta untuk mengelompokkan jenis kata dari bacaan tersebut. Sesuai dengan salah satu tujuan membaca menurut Anderson dalam Tarigan, 2009:10 menyebutkan pada bagian e membaca untuk mengelompokkan, membaca untuk mengklasifikasikan (reading to classify).

\section{METODE}

Metode penelitian yang digunakan dalam penelitian ini adalah eksperimen dengan desain pretest and posttest control group desaign. Tujuan dari desain ini adalah untuk meneliti ada tidaknya hubungan sebab akibat yang menggunakan perlakuan oleh salah satu kelompok (kelas eksperimen) serta dibandingkan hasilnya dengan kelompok yang tidak memakai perlakuan (kelas kontrol). Populasi yang dijadikan dalam penelitian ini adalah siswa kelas IX SMPN 1 Susukan Kabupatén Cirebon Taun Ajaran 2014/2015 yang jumlahnya delapan kelas. Adapun penarikan sampel dalam penelitian ini yaitu menggunakan teknik purposive sampling. Pengklasifikasian kelas IX SMPN 1 Susukan menggunakan kriteria yang menunjukkan perlakuan sama baik dalam prestasi siswa, jumlah siswa, keadaan siswa, guru yang mengajar, buku sumber, maupun kurikulum yang dipakainya. Dengan karakteristik yang sama tersebut akhirnya diambil sampel, dua kelas, kelas IXB selaku kelas eksperimen dan kelas IX-G selaku kelas kontrol.

\section{HASIL DAN PEMBAHASAN}

Kemampuan kosakata dalam pembelajaran membaca karangan eksposisi siswa terbagi dalam kelas eksperimen dan kelas kontrol. 
Kemampuan kosakata dalam membaca karangan eksposisi siswa kelas ekperimen

Kemampuan kosakata dalam membaca karangan eksposisi siswa kelas eksperimen terbagi dalam kemampuan awal sebelum memakai metode terjemahan tata bahasa dan kemampuan ahir setelah memakai metode terjemahan tata bahasa.

Hasil yang dicapai bisa dilihat dari tabel berikut.

Tabel 1: Hasil Rata-Rata Sebelum dan Sesudah Memakai Metode Terjemahan Tata Bahasa

\begin{tabular}{|c|c|c|c|}
\hline Komponen & Rata-rata & Rata-rata & Kenaikan \\
\hline \multicolumn{4}{|l|}{ Kelas Eksperimen : } \\
\hline 1. Kata Depan & 20,70 & 29,91 & 9,21 \\
\hline 2. Kata Kerja & 6,51 & 7,60 & 1,09 \\
\hline 3. Kata Sipat & 8,42 & 11,14 & 2,72 \\
\hline 4. Kata Bilangan & 3,40 & 4,95 & 1,55 \\
\hline 5. Kata Keterangan & 2,84 & 6,30 & 3,46 \\
\hline 6. Kata Sambung & 2,35 & 4,47 & 2,12 \\
\hline 7. Kata Depan & 2,63 & 4,07 & 1,44 \\
\hline Total & 46,84 & 68,44 & 21,60 \\
\hline
\end{tabular}

Nilai rata-rata prates di kelas eksperimen sebelum dilakukan pembelajaran yang tidak menggunakan metode terjemahan tata bahasa adalah sebesar 46,84. Setelah dilakukan pembelajaran yang menggunakan metode terjemahan tata bahasa, nilai rata-ratanya naik menjadi 68,44 atau naik sebesar 21,60. Hal ini menunjukkkan hasil pembelajaran di kelas eksperimen yang menggunakan metode terjemahan tata bahasa mampu meningkatkan nilai rata-rata hasil pembelajaran. Peningkatannya lebih besar daripada peningkatan nilai rata-rata di kelas kontrol setelah dilakukan pembelajaran yang tidak menggunakan metode terjemahan tata bahasa.

\section{Kemampuan kosakata dalam membaca} karangan eksposisi siswa kelas kontrol

Kemampuan kosakata dalam membaca karangan eksposisi siswa kelas kontrol terbagi dalam kemampuan awal sebelum dan sesudah tidak memakai metode terjemahan tata bahasa.

Hasil yang dicapai bisa dilihat dari tabel berikut.

Tabel 2: Hasil Rata-Rata Sebelum dan Sesudah Memakai Metode Terjemahan Tata Bahasa

\begin{tabular}{|c|c|c|c|}
\hline Komponen & Rata-rata & Rata-rata & Kenaikan \\
\hline \multicolumn{4}{|l|}{ Kelas Kontrol : } \\
\hline 1. Kata Depan & 23,30 & 26,53 & 3,23 \\
\hline 2. Kata Kerja & 8,14 & 8,35 & 0,21 \\
\hline 3. Kata Sipat & 8,14 & 10,93 & 2,79 \\
\hline 4. Kata Bilangan & 3,26 & 4,23 & 0,97 \\
\hline 5. Kata Keterangan & 2,56 & 4,72 & 2,16 \\
\hline 6. Kata Sambung & 2,77 & 4,37 & 1,60 \\
\hline 7. Kata Depan & 2,51 & 3,95 & 1,44 \\
\hline & 50,67 & 63,00 & 12,33 \\
\hline
\end{tabular}


Nilai rata-rata prates di kelas kontrol sebelum dilakukan pembelajaran yang tidak menggunakan metode terjemahan tata bahasa adalah sebesar 50,67. Setelah dilakukan pembelajaran yang tidak menggunakan metode terjemahan tata bahasa, nilai rata-ratanya naik menjadi 63,00 atau naik sebesar 12,33. Hal ini menunjukkkan hasil pembelajaran di kelas kontrol yang tidak menggunakan metode terjemahan tata bahasa mampu meningkatkan nilai rata-rata hasil pembelajaran. Meskipun demikian, peningkatannya lebih kecil daripada peningkatan nilai rata-rata di kelas eksperimen setelah dilakukan pembelajaran yang menggunakan metode terjemahan tata bahasa.

Berdasarkan uraian di atas, maka pembelajaran di kelas eksperimen yang menggunakan metode terjemahan tata bahasa lebih efektif daripada di kelas kontrol yang tidak menggunakan metode terjemahan tata bahasa.

\section{Uji Hipotésis}

Hipotesis penelitian ini adalah "Metode terjemahan tata bahasa lebih efektif daripada yang tidak memakai metode terjemahan tata bahasa untuk meningkatkan keampuan kosakata dalam membaca karangan eksposisi siswa kelas IX SMPN 1 Susukan Kabupatén Cirebon". Berdasarkan olah data dengan menggunakan komputer (program SPSS) didapatkan nilai $\mathrm{t}$ dan signifikansinya sebagai berikut:

Tabel 3

Hasil Uji t (Uji Beda)

\begin{tabular}{clccc}
\hline No. & \multicolumn{1}{c}{ Perbedaan } & Nilai t & Signifikansi & Katerangan \\
\hline 1. & $\begin{array}{l}\text { Nilai prates di kelas kontrol dan } \\
\text { nilai pascates di kelas eksperimen }\end{array}$ & 1,498 & 0,142 & $\begin{array}{c}\text { Tidak } \\
\text { Signifikan }\end{array}$ \\
\hline 2. & $\begin{array}{l}\text { Nilai prates dan nilai pascates di } \\
\text { kelas kontrol }\end{array}$ & 8,147 & 0,000 & Signifikan \\
\hline 3. & $\begin{array}{l}\text { Nilai prates dan nilai pascates di } \\
\text { kelas eksperimen }\end{array}$ & 10,376 & 0,000 & Signifikan \\
\hline 4. & $\begin{array}{l}\text { Nilai pascates di kelas kontrol dan } \\
\text { nilai pascates di kelas eksperimen }\end{array}$ & 2,196 & 0,034 & Signifikan \\
\hline
\end{tabular}

Berdasarkan data di atas, bisa dijelaskan bahwa:

1) Tidak ada beda yang signifikan antara nilai prates di kelas kontrol dan nilai pascates di kelas eksperimen dengan nilai t 1,498 dan signifikansinya 0,142 . Tidak ada beda yang signifikan disini artinya kemampuan kosakata dalam membaca karangan eksposisi siswa di kelas kontrol dan di kelas eksperimen sebelum dilakukan pembelajaran, baik yang memakai metode terjemahan tata bahasa maupun yang tidak memakai metode terjemahan tata bahasa hasilnya relatif sama.
2) Ada perbedaan yang signifikan antara nilai prates dan pascates di kelas kontrol dengan nilai $t \quad 8,147$ dan signifikansinya 0,000 . Ada perbedaaan di sini artinya pembelajaran membaca karangan eksposisi yang tidak memakai metode terjemahan tata bahasa efektif dalam meningkatkan kemampuan kosakata dalam membaca karangan eksposisi.

3) Ada perbedaan yang signifikan antara nilai prates dan pasca tes di kelas eksperimen dengan nilai t 10,376 dan signifikansinya 0,000 . Ini berarti pembelajaran membaca karangan eksposisi yang memakai metode 
terjemahan tata bahasa efektif untuk meningkatkan kemampuan kosakata dalam membaca karangan eksposisi. Nilai t di kelas eksperimen 10,376 lebih tinggi daripada nilai t di kelas kontrol 8,147. Artinya, hasil kosakata dalam membaca karangan eksposisi di kelas eksperimen yang memakai metode terjemahan tata bahasa lebih efektif daripada hasil kosakata dalam membaca karangan eksposisi di kelas kontrol yang tidak memakai metode terjemahan tata bahasa.

4) Ada beda yang signifikan antara nilai pascates di kelas kontrol dan nilai pascates di kelas eksperimen dengan nilai t 2,196 dan signifikansinya 0,034 . Hal ini menunjukan bahwa kemampuan kosakata dalam membaca karangan eksposisi di kelas eksperimen yang memakai metode terjemahan tata bahasalebih efektif daripada pembelajaran membaca karangan eksposisi di kelas kontrol yang tidak memakai metode terjemahan tata bahasa.

Berdasarkan uraian di atas, bisa disimpulkan bahwa metode terjemahan tata bahasa untuk meningkatkan kemampuan kosakata dalam membaca karangan eksposisi siswa kelas IX SMPN 1 Susukan Kabupatén Cirebon. Artinya, Ha (hipotésis altérnatif) ditarima jeung Ho (hipotésis nol) ditolak.

Kata yang mampu dikelompokkan diantaranya;

1) Kata benda, saperti; seuneu, soga kayu, kaén mori, kaén, panci, celemek, tangkal, pewarna, banjar balong, singa payung, singa barong, patran keris, ayam alas, burung gelatik, semarangan, kanco, kaén pelindung, kompor, mega mendung, batik Cirebon pesisir, batik klasik, tembokan, bujursangkar, canting éléktronik, cangkudu, tangkal pace, kapal kompeni, pekalis, penari cina, semarangan, lilin malam, gawangan, canting, burung gelatik, awi, katun, kai, pangjepit, sutra, blok.
2) Kata kerja, seperti: ngabébérkeun, nyieun, ngaitkeun, ngabatik, ngawarnaan, ngajepit, manaskeun.

3) Kata sifat, seperti: gancang, panas, hampang, kandel, konéng, beureum, semu konéng, kandel, nguap, hideung, hadé, leutik.

4) Kata bilangan: dua, 120, hiji, mangbulan-bulan, mangmingguminggu.

5) Kata keterangan, seperti: di handap, di luhur, kiwari, sabada, saméméh.

6) Kata sambung, seperti: jeung, atawa, sedengkeun, pikeun, lamun, sanajan.

7) Kata depan, seperti: di, tina, dina, kana.

Karena itu seperti yang dikemukakan (Tampubolon, 1987:6), bahwa membaca bisa meningkatkan daya nalar salahsatu cara dalam mengajarkannya yaitu dengan menggunakan MTTB.

\section{SIMPULAN}

Berdasarkan hasil penelitian, analisis dan pembahasan dapat disimpulkan bahwa metode terjemahan tata bahasa memberikan pengaruh yang signifikan terhadap kemampuan kosakata siswa dalam membaca karangan eksposisi. Dengan kata lain, metode teremahan tata bahasa lebih efektif daripada yang tidak memakai metode terjemahan tata bahasa dalam meningkatkan kemampuan kosakata dalam membaca karangan eksposisi siswa kelas IX SMPN 1 Susukan kabupaten Cirebon taun ajaran 2014/2015. Oleh karena itu, MTTB ini dapat dijadikan salah satu metode alternatif dalam pembelajaran membaca.

\section{PUSTAKA RUJUKAN}

Nurhadi. 2010. Bagaimana Meningkatkan Kemampuan Membaca. Bandung: Algensindo

Syafi'ie, Imam. 1999. Pengajaran Membaca Terpadu. Malang: IKIP.

Tampubolon. 1987. Kemampuan Membaca, Tehnik Membaca Efektif dan Efisien. Bandung: Angkasa. 
Tarigan, Henry Guntur. 2008. Membaca Sebagai Keterampilan Berbahasa. Bandung: Angkasa.

Tarigan, Henry Guntur. 2009. Metodologi Pengajaran Bahasa 1. Bandung: Angkasa.

\section{UCAPAN TERIMA KASIH}

Ucapan terima kasih saya sampaikan kepada pihak-pihak yang membantu penelitian ini, terutama kepada pembimbing tesis yang telah memberi motivasi kepada penulis. Selain itu, terima kasih pula saya ucapkan kepada penyunting Jurnal Lokabasa yang berkenan memuat tulisan ini. 